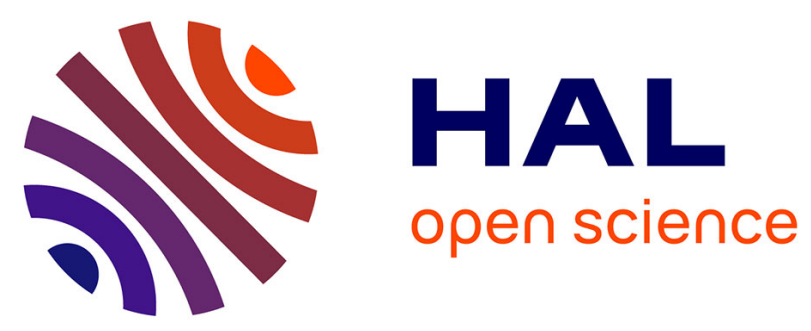

\title{
An ex-ante evaluation of the use of seasonal climate forecasts for millet growers in SW Niger
}

Philippe Roudier, Benjamin Sultan, Philippe Quirion, Christian Baron, Agali Alhassane, Seydou B. Traoré, Bertrand Muller

\section{> To cite this version:}

Philippe Roudier, Benjamin Sultan, Philippe Quirion, Christian Baron, Agali Alhassane, et al.. An ex-ante evaluation of the use of seasonal climate forecasts for millet growers in SW Niger. International Journal of Climatology, 2012, 32, pp.759-771. 10.1002/joc.2308 . hal-00614812

\section{HAL Id: hal-00614812 https://hal.science/hal-00614812}

Submitted on 16 Aug 2011

HAL is a multi-disciplinary open access archive for the deposit and dissemination of scientific research documents, whether they are published or not. The documents may come from teaching and research institutions in France or abroad, or from public or private research centers.
L'archive ouverte pluridisciplinaire HAL, est destinée au dépôt et à la diffusion de documents scientifiques de niveau recherche, publiés ou non, émanant des établissements d'enseignement et de recherche français ou étrangers, des laboratoires publics ou privés. 


\section{An ex-ante evaluation of the use of seasonal climate forecasts for millet growers in SW Niger}

Roudier, P. ${ }^{1, a}$, Sultan, B. ${ }^{2}$, Quirion, P. ${ }^{1}$, Baron, C. ${ }^{3}$, Alhassane, A. ${ }^{4}$, Traoré, S. B. ${ }^{4}$, Muller, $\mathrm{B}^{5}$

${ }^{1}$ CIRED. Campus du Jardin Tropical. 45 bis, avenue de la Belle Gabrielle, 94736 Nogent-surMarne Cedex, France

${ }^{2}$ IRD-LOCEAN, Paris

${ }^{3}$ CIRAD, Montpellier

${ }^{4}$ AGHRYMET Regional Center, Niamey

${ }^{5}$ CIRAD, Thiès

${ }^{a}$ Corresponding author: roudier@ centre-cired.fr. Tel: 00331 43.94.73.67. 


\begin{abstract}
:
This work assesses the value of climate forecasts for millet growers in Niger. We quantify the potential value of three kinds of categorical forecasts assigning cumulated rainfall during the forthcoming rainy season by tercile (dry, normal or humid): (i) a realistic imperfect tercile forecast; (ii) a perfect tercile forecast and (iii) a perfect tercile forecast which includes a prediction of rainy season onset and offset dates. Eighteen management strategies are assessed. Corresponding yields are computed using the SARRA-H crop model then converted into utility by taking into account risk-aversion. Simulations over an historical 18 -year period 1990-2007 show that benefit is lowest with imperfect tercile forecasts $(+6.9 \%)$, higher $(+11 \%)$ with perfect tercile forecasts, and reaches $+31 \%$ when enhanced adaptation strategies and additional climatic indices are available. These results show that improving existing forecast systems by including the prediction of onset and cessation of rainfall is of great value.
\end{abstract}

Keywords: agriculture, Niger, millet, seasonal forecast, Africa, risk aversion

\title{
1. Introduction
}

Food security is a serious concern in Sub-Saharan Africa where the rate of undernourished population is over $30 \%$, the highest in the world. The future of this region, characterized by a fragile balance between limited natural resource availability and the pressure of a growing population, depends on the capability of the agricultural sector to guarantee food security for the vast majority of people. If the global production of staple food in this region has increased in past decades, it is mainly due to field expansion as crop productivity has stagnated since the 1980s, and even decreased in some countries, for example, Niger (-9\% in average for millet between 1961/1970 and 1998/2007, FAOSTAT data). In such a situation, there is a real need to increase yields. Among the numerous possible 
technical options (e.g. water harvesting, intercropping, microfertilization), the use of climate forecasts is a promising and costless one that might help African farmers to take crucial strategic decisions that would reduce their vulnerability and increase farm profitability. Indeed, in regions where rainfed agriculture is the main source of food and income, dealing with the uncertainty of climate is a challenge for agriculture as farmers need to make critical climate-sensitive decisions months before the rainy season starts. Field studies show promising results (Patt et al., 2005; Hellmuth et al., 2007).

Thanks to improved climate knowledge, it is now possible to produce reliable predictions of climate fluctuations in many parts of the world (e.g. the rainy season in Africa) at seasonal lead time (Hansen, 2002). These forecasts are made with simple statistical methods (Letson et al., 2009; Patt et al., 2005), with more sophisticated tools such as Global and/or Regional Climate models (GCMs/ RCMs) (Hansen et al., 2009; Cooper et al., 2008), or with both. In West Africa, National Meteorological Agencies have collaborated with European and American climate forecasting groups since 1998 through the framework of the regional climate outlook forum PRESAO (French acronym for PREvisions Saisonnières en Afrique de l'Ouest; Hamatan et al., 2004). In spring each year, it provides a qualitative consensual forecast of the coming rainy season based on a combination of different sources of information: GCMs and national models based on a statistical approach (Konte, 2007). National meteorological offices then broadcast this seasonal forecast throughout West Africa so that end-users, such as farmers, can put it to efficient use.

However, the evaluation of the potential benefit of seasonal forecasts in Africa is very rare (Sultan et al. 2009; Meza et al. 2008), especially for food crops. Indeed, even if seasonal forecasts are made routinely in Sub-Saharan Africa, adoption by farmers is too low to provide any reliable ex-post evaluation that would assess observed outcomes following the adoption of actual forecast schemes (Meza et al., 2008; Roncoli et al., 2000). This paper is, to our 
knowledge, the first attempt to estimate the value of seasonal forecasts for food crops in West Africa. The best way to evaluate the forecasts is an ex-ante approach (Sultan et al., 2009; Meza et al., 2008). First, it provides the quantitative arguments that are often necessary to mobilize funds and institutional partners and to focus on where the benefits are likely to be the greatest (Thornton, 2006; Meza et al., 2008). Second, it allows for possible new climate indices to be evaluated. The former is highly relevant because forecasts computed in West Africa (e.g PRESAO) focus mainly on seasonal rainfall amount, whereas onset and cessation dates influence the implementation of adaptation strategies in response to forecasts (Ingram et al., 2002).

For our purpose, we focus on millet [Pennisetum glaucum (L.) R. Br.] in Niger which is the main staple food in the country ( $75 \%$ of the national total production) and is produced entirely under rainfed conditions in traditional smallholder farming systems with low off-farm input (Amadou et al., 1999, FAOSTAT data; Soler et al., 2008). We develop an integrated methodology that (i) defines possible management strategies in response to forecasts, (ii) computes yields for each strategy using the SARRA-H crop model, (iii) computes income for each strategy and (iv) simulates farmer's choice using a Constant Relative Risk Aversion (CRRA) utility function. This methodology is then used to assess the potential economic value of seasonal forecasts for millet producers in Niger. To be consistent with the existing categorical climate prediction systems in West Africa (PRESAO; see http://www.acmad.fr; Hamatan et al. 2004), we will focus on forecasts of total rainfall categorized according to the terciles of the expected distribution of values: humid (upper tercile), normal (middle tercile) and dry (lower tercile). We consider three types of categorical forecasts: (i) a realistic imperfect tercile forecast that mimics actual seasonal forecasts using sea-surface-temperature indices to predict rainfall; (ii) a perfect tercile forecast and (iii) the same perfect tercile 
forecast but with the addition of predicted onset and offset dates for the coming rainy season. The value of each forecast is examined over an historical 18-year period from 1990 to 2007.

\section{Materials and Methods}

\subsection{Area and data}

We focus on SW Niger (Figure 1) located in the Sahelo-Sudanian zone (Abdoulaye and Sanders, 2005). This region is characterized by a typical semi-arid climate defined by a rainy season lasting approximately from June to September which provides around 500 $\mathrm{mm} /$ year with high spatial variability (Balme et al., 2005), even for neighbouring stations. Agriculture is rainfed and characterized by low input use, limited access to credit and low yields. Most soils are sandy and deficient in $\mathrm{P}$ and $\mathrm{N}$.

In this area, we use daily data from 30 raingauges and one meteorological station (1990/2007) throughout the AMMA-CATCH Niger program (Cappelaere et al., 2009) which provides data with a high spatial and temporal density. Another dataset collected by the AGRHYMET Regional Centre provides detailed agronomic data (variety, sowing date, yields) in 10 villages (Alhassane 2009) for the years 2004/2008. This dataset has been used to calibrate the crop model so this study focuses on those 10 villages.

Missing daily rainfall data have been filled through a statistical procedure. Only two stations among thirty have more than $10 \%$ data missing $(10.6 \%$ and $16 \%)$ which is the commonly used acceptability threshold (Romero, 1998). It is possible to supplement such data using other methods (see e.g. Coulibaly and Evora (2008), Garcia et al. (2006)). Teegavarapu et al. (2005), in a comparative study of such methods, recommend two of them in particular. 
We chose the simplest one, the Coefficient of Correlation Weighting Method. Missing data $\theta$ at station $\mathrm{m}$ are calculated as shown in equation 1.

$$
\theta_{\mathrm{m}}=\frac{\sum_{\mathrm{i}=1}^{\mathrm{n}} \theta_{\mathrm{i}} \mathrm{R}_{\mathrm{m}, \mathrm{i}}}{\sum_{\mathrm{i}=1}^{\mathrm{n}} \mathrm{R}_{\mathrm{m}, \mathrm{i}}}
$$

where R is Pearson's correlation coefficient between station $\mathrm{m}$ and another station $\mathrm{i} . \mathrm{n}$ is the number of stations considered for correlations.

Following Teegavarapu et al., we only consider the 4 stations $(\mathrm{n}=4)$ with the highest $\mathrm{R}$ computed for years 1990/2006. Using 2007 to assess this method, we compare simulated data $\theta$ with real data. For all stations, $R_{\text {mean }}$ (correlation) value is $0.83, R_{\min }=0.61$ and $R_{\max }=0.96$. Moreover, in Table 1 we assess the "hit rate" of this method. Four intervals are created and a diagonal represents the hit rate. This method performs well for low rainfall value but is more problematic for rain events $>10 \mathrm{~mm}$, especially $] 10 \mathrm{~mm} ; 20 \mathrm{~mm}$ ]. However, unacceptably high errors remain rare.

\subsection{The SARRA-H software and the simulated yields}

The crop model used in this study, SARRA-H version millet V.2, is particularly suited to the analysis of climate impacts on cereal growth and yield in dry tropical environments (Kouressy et al., 2008; Dingkuhn et al., 2003; Sultan et al., 2005; Baron et al., 2005). SARRA-H is a simple, deterministic crop model for cereals operating in daily time steps. It was developed from SARRA, the water balance model used by agronomists and agrometeorologists in West Africa (Samba, 1998) for sorghum and millet. SARRA-H simulates attainable yields according to crop (variety) features, including potential yield, and climate conditions. Millet is the only crop we model. Although other crops are cultivated (e.g. 
cowpea, sorghum) in Niger, millet is by far the main one. Egg and Wade (2006) show also that the proportion of millet in Niger is increasing.

The model has been calibrated on local varieties through agronomical trials at the AGRHYMET Regional Centre (Alhassane, 2009) in order to correctly simulate their development under good agronomical conditions. Then comparisons were made with data coming from farmers' fields and the standard parameter sets were slightly modified (basically by reducing radiation use efficiency coefficient) in order to obtain smaller biomass development and yields similar to those observed on average in farmers' fields.

It is important to notice that SARRA-H simulates potential yields based only on meteorological data, but other parameters are very important, e.g., birds, pests and diseases due to excess moisture. This damage reduces potential yields and is linked to the adequacy between the crop cycle and the timing and length of the rainy season. We thus define two criteria, subsequently called degradation criteria:

(i) a crop (with its sowing date) is considered inadequate if the $1^{\text {st }}$ day of the maturation phase happens more than 20 days before the average cessation date of the rains. Indeed, Kouressy et al. (2008) note for sorghum as well as for millet (Haussmann, personal communication) that, when flowering occurs too early in the rainy season, there are frequently losses due to pests, birds and diseases (excess of moisture).

(ii) a crop (with its sowing date) is considered as inadequate if the sowing date is after the onset of the rainy season as this might reduce yields due to $\mathrm{N}$ leaching, lower radiation and temperatures, aggressive rainfall impact on younger shoots, water-logging, pest pressure, but mostly because of competition from weeds (Traore et al., 2007).

When a couple (crop, sowing date) does not match one criterion or both, we reduce the yield simulated by SARRA-H by applying an empirical scale factor described in Fig.2. 


\subsection{Farmers' need for forecast, and management strategies}

To compute the value of seasonal forecasts, it is necessary to define the available farm management strategies. Meza et al. (2008) emphasize that studies of seasonal forecasts generally underestimate their potential value because they take too few strategies into account. Yet, as shown by Luseno et al. (2003), the study of farm management strategies is very important: the final value of forecasts depends mainly on farmers' response capacity. We are not aware of any specific study on this topic in Niger, but other studies in Africa provide some information about what farmers would do (Table 2). According to Roncoli et al. (2008), farmers from Burkina Faso could use between 0 and 4 strategies, with $38 \%$ of them using only one and $27 \%$ two strategies.

Some studies (e.g. O’Brien et al., 2000) show that forecasts would not really change farmers' practices: this may be due to fatalism, or a lack of trust because of other local forecasting systems. However, it does not necessarily mean that seasonal forecasts are useless, rather that there is a problem with the information format. It must be easy to understand and, especially, must be delivered at the right time, i.e. at least one month before the beginning of the season (Ingram et al., 2002) so that farmers have time to buy seeds and fertilizers. Although the value of such a forecast depends on users' acceptance, this is beyond the scope of the present paper, so we assume that farmers use the delivered forecast.

Farmers generally say that they would change millet variety, sowing date and fertilization level if they had information about the onset and offset of the rainy season, and the amount and distribution of rains within the season. We therefore consider three types of response to forecasts (summarized in Figure 3).

\subsubsection{The choice of millet variety}


Three varieties are used in this study. Two of them (Hainy Kirey and Somno) are grown in situ (Bezançon et al., 2008), the second less frequently than the first. They are photoperiod sensitive, that is, they adapt their cycle length in order to flower around the same date (Vaksmann et al. 1996, Dingkuhn et al.2006). The third one, Souna III, is an improved variety which is not photoperiodic and is supposed to have a higher potential yield. Yet farmers tend to avoid it, maybe because of its high inter-seasonal yield variability, or because of losses due to early maturation (de Rouw, 2004). These varieties have different cycle durations: about 85 days for Souna, 90 days for HK and 120 days for Somno. Although Souna is not used in situ, we selected it because of its potential productivity and short cycle: with forecasts, it might be used for late seasons.

\subsubsection{The choice of sowing dates}

Three sowing dates are defined:

(i) Farmer Sowing Date (FSD) is simulated by the SARRA-H crop model. Farmers usually sow when one or more rains have filled the surface reservoir (more than $10 \mathrm{~mm}$ of water stocked at the end of the day i.e. after daytime evaporation). If the biomass growth is negative at least 11 days during the 20 first days, the first sowing fails: the farmer has to re-sow. A first validation of this method has been done using 4 years of observed data in the 10 villages around Niamey.

(ii) ONset based Sowing Date (ONSD): millet is sowed at the onset, as it is defined by Sivakumar (1988) and used by several authors (e.g. Balme et al., 2005 which defines it as “agricultural onset"). ), This sowing date, rather than the climatologists' monsoon onset (see 
e.g. Sultan et al., 2005) has been created to obtain optimal yields: it is supposed to be beneficial for farmers.

(iii) OFfset based Sowing Date (OFSD) tries to solve the problem of losses when crop maturation is too early in the rainy season, as described earlier. The offset is computed following Sivakumar's criterion (1988): 20 consecutive dry days after September $1^{\text {st }}$. Following Kouressy et al., (2008) who consider that a crop (with a sowing date) is not adequate if the $1^{\text {st }}$ day of the maturation phase happens more than 20 days before the offset, we create a new sowing date by fitting the $1^{\text {st }}$ day of maturation 10 days before the onset. This value of $10 \mathrm{~d}$ is optimal as, for HK and Somno, the cycle duration has a $20 \mathrm{~d}$ variation. Finally the OFSD is calculated by subtracting to offset: $97 \mathrm{~d}$ for HK, $116 \mathrm{~d}$ for Somno and $67 \mathrm{~d}$ for Souna. This is particularly relevant for Souna as photoperiod sensitive varieties (HK and Somno) modify their cycle to flower at the same date every year. However, their photoperiod sensitivity is not very strong and there is a variation of maturation date from year to year. So, even if the OFSD is more powerful with Souna (constant cycle), this is suited for HK and Somno. Note that ONSD and OFSD require perfect information about the onset and the offset.

\subsubsection{Choosing the level of fertilization}

Finally, even if fertilizers (at least chemical fertilizers) are not widely used in Niger, we introduce this option as a response to forecasts. Indeed, with seasonal forecasts, fertilizers might be used when a humid year is anticipated. We suppose that farmers are able to buy a common chemical fertilizer, NPK 15-15-15. Following a study of ICRISAT (International Crops Research Insitute for the Semi-Arid Tropics) cited by FAO (2002), we suppose that farmers use $60 \mathrm{~kg} / \mathrm{ha}$ of NPK (microfertilization). This is a common practice which provides good results. We also need to take into account farmers' use of organic fertilizer, such as 
manure ( $30 \%$ according to observed data). In the simulation, manure is free and used every year at the observed rate $(30 \%)$. So, in all the following sections, "NFert" means "No chemical fertilizers" and "Fert" "with chemical fertilizers". In both cases, there is free organic fertilization.

Based on these 3 degrees of freedom (varieties, sowing dates, fertilizers use), we define 18 farm management strategies (Figure 3). We next simulate with SARRA-H the yield for each strategy, for each of the 10 stations (Figure 1) and for the years 1990 to 2007.

\subsection{Scenarios considered}

Three forecasting scenarios (and one control) are considered in this paper.

\subsubsection{Imperfect categorical forecasts of cumulated summer rainfall}

In order to evaluate plausible seasonal forecasts, such as the ones from PRESAO, we build our own simple statistical model to predict Niger summer rainfall. A number of empirical studies have been made using pre-rainy season SST to predict the summer Sahelian rainfall total (Folland et al. 1991; Ward 1998 ; Ward et al. 2004; Sultan et al. 2009). For these studies, we based our rainfall prediction on SST data from the monthly extended reconstructed sea surface temperature (ERSST). This is built using the most recently SST data available from the International Comprehensive Ocean-Atmosphere Data Set (ICOADS) and improved statistical methods that allow stable reconstruction using sparse data (Smith et al. 2008). Only the SST data over the 1990-2007 period is used in this study. We first compute three lagged correlation maps between the Niger summer rainfall and SST respectively in March, April and May. The correlation maps are then used to select a set of predictors that are box-averages of SST over specific regions known to be linked with the West African monsoon (mainly in the Atlantic Ocean and in the Pacific Ocean; see Ward 1998, Giannini et 
al, 2003) where the highest significant correlations are found. These predictors are then used to build a stepwise multivariate linear regression model in order to predict the Niger summer rainfall. The multivariate model is described in equation 2 :

$$
Y=\alpha+\beta_{1} X_{1}+\cdots+\beta_{p} X_{p}
$$

$Y$ represents the predicted summer Niger rainfall value, $\alpha$ is a constant, and each $\beta$ term denotes a regression coefficient for the corresponding SST predictor $X$ for a given month. Once a first model is built with all predictors, we reduce the number of predictors by minimizing the variance inflation factor to reduce colinearity among predictors. In the same way, we apply ascendant and descendant methods to choose the best set of predictors among the initial set. Finally we retain a model based on two SST predictors in April (one in the Pacific and the other in the Atlantic Ocean) with a cross-validated coefficient of correlation of $\mathrm{R}=0.70$. We then transform the predicted rainfall into binary time series where only three outcomes are possible, "humid", "normal", or "dry", where the predicted rainfall of the year is above the upper tercile, between the upper and the lower tercile or below the lower tercile of the 17 years rainfall distribution, respectively. Since this categorical forecast contains errors (a humid year can be predicted as dry for instance), we call it the imperfect tercile forecast (“Impft”).

\subsubsection{Perfect categorical forecasts of the cumulated summer rainfall}

In order to see if it is worth improving the accuracy of such a forecast, we consider another scenario (later called "Pft") with a perfect categorical forecast of the rainy season: we therefore cluster years 1990-2007 into 3 groups of the same size (6 years in each) according to the observed cumulated rainfall. The differences for each year in the clustering between scenarios "Impft" and "Pft" are described in Table 3. It is noticeable that both scenarios give the same tendency for 9 years (4 dry, 2 normal and 3 humid years). 


\subsubsection{Forecast of the seasonal rainfall with rainy season onset and cessation dates}

Since the onset and cessation dates of the rainy season are very important for farmers (Laux et al., 2007) and have been investigated in recent climate observation and modelling studies (Sultan and Janicot, 2003 ; Druyan et al., 2009), we consider an enhanced forecast system "Pft++" which provides the same perfect tercile forecast as "Pft" but with the prediction of the onset and cessation of the rainy season. This additional climate information enables the use of ONSD or OFSD as a response to the forecasts and to assess the additional economic value of improving existing forecast systems.

\subsubsection{Control scenario}

Finally, we define a control scenario (Ctrl; Table 4) where no forecast is available. It is used as a benchmark to quantify the benefits of the use of forecasts. To sum up, 4 scenarios are studied (Table 4): Impft, Pft, Pft++ and Ctrl.

\subsection{Farmers' decision rule}

We assume that the farm we are considering has 3 plots of 0.5 ha each. On these 3 plots, it is possible to use different farming practices (all combinations are considered): for example, the farmer is able to take a risky decision on 0.5 ha (high yield but high inter annual variability) and keep the other two plots as a 'safety net' (normal yield, low variability).

We simulate farmers' decisions on the best strategy in response to each forecast available (Table 4). It is important to note that African farmers are risk averse (Brüntrup, 2000). They not only maximize their income but also minimize the risk of being in a bad situation due to crop failure (de Rouw, 2004). The challenge is then to find safe strategies that improve the average income. There are different ways of simulating risk aversion (see 
Ogurtsov et al., 2008, for a review). We assume here that farmers maximise a CRRA utility function (see equation 3) which has been widely used in similar cases (e.g. Holt and Laury (2002) or Letson et al., 2009). Chavas and Holt (1996) as well as Pope and Just (1991) conclude that the CRRA function is appropriate to describe farmers' behaviours.

$$
\mathrm{U}(\mathrm{x})=\frac{\mathrm{x}^{1-\phi}}{1-\phi}, x>0, \phi \neq 1
$$

For each station $s t=\{1 \ldots 10\}$, each scenario $s c=\{\mathrm{Impft}, \mathrm{Pft}, \mathrm{Pft}++, \mathrm{Ctrl}\}$ and each forecast $f$, we compute the set of management strategies it which maximises expected utility EU, as described in equation 4. Note that we use the function $\mathrm{U}(\mathrm{x}+\mathrm{W})-\mathrm{U}(\mathrm{W})$ in order to have a null utility when the farmers' income is zero.

$$
\begin{aligned}
& E U^{s t, s c, f}=\frac{1}{(1-\phi)} *\left(\frac{1}{n} \sum_{i=1}^{n}\left(\left(\left(\sum_{j=1}^{3} Y_{i, j}^{s t, s c, f}\left(i t_{j}^{s t, s c, f}\right)\right)+W\right)\right)^{(1-\phi)}-W^{(1-\phi)}\right) \\
& \phi \geq 0, \phi \neq 1, W \geq 0
\end{aligned}
$$

Where $Y$ is the farmer's income related to millet production which will be described below in more detail, $i \in(1 \ldots n)$ indicates the year $(\mathrm{n}=18$ if $\mathrm{sc}=\mathrm{Ctrl}$, otherwise $\mathrm{n}=6), \quad j \in(1,2,3)$ indicates the plot, $W$ is the farmers' income independent from millet production and $\Phi$ is the relative risk aversion parameter. We now detail these three variables and parameters in turn. $Y_{i, j}^{s t, s c, f}\left(i t_{j}^{s t, s c, f}\right)$ is expressed in FCFA, Niger monetary unit $(1 €=655.957$ FCFA $)$. It is the gross margin, i.e. the value of millet production, net of the cost of fertilizers (for the management strategies with fertilizers). The calculation is detailed in equation 5 .

$$
Y_{i, j}^{s t, s c, f}\left(i t_{j}^{s t, s c, f}\right)=P_{i} \cdot Q_{i, j}^{s t, s c, f}\left(i t_{j}^{s t, s c, f}\right)-C_{i} \cdot F_{j}^{s t, s c, f}\left(i t_{j}^{s t, s c, f}\right)
$$

Where $P$ is the millet sellers' price (in FCFA/kg) from the FAO, $Q$ is the quantity produced (in $\mathrm{kg}$ ), $C$ is the fertilizer cost per plot (in FCFA/kg), provided by Centrale d'approvisionnement de la République du Niger, and $F$ is the quantity of fertilizers for each 
plot, if any (in kg). Following a study of ICRISAT cited by FAO (2002), we suppose that farmers use $60 \mathrm{~kg} / \mathrm{ha}$ of NPK 15-15-15 (microfertilization) which is a common practice.

$W$ is the farmers' wealth independent of millet production. It includes off-farm income and initial wealth. We compute the mean annual gain $W$ on all stations, for the whole period and for a management strategy using only traditional sowing date (FSD), variety HK and no fertilization. This cropping strategy is by far the most used in situ. This finally means that $\mathrm{W}=60700$ FCFA.

$\Phi$ is the relative risk aversion parameter. The higher $\Phi$, the more risk averse is the farmer; $\Phi=0$ means that he is risk-neutral. Various methods have been used to estimate parameter $\Phi$ and empirical results vary greatly. A recent estimate by Chiappori and Paiella (2008, p. 19) concludes that "the median of the distribution of relative risk aversion could be slightly smaller than 2". Schechter (2007), using data from rural Paraguay, concludes that, when individuals cannot save, a reasonable assumption for African farmers, the average coefficient of relative risk aversion is 1.92 . Based on these recent studies, we use $\Phi=2$ in the results presented in this paper. Since some other studies, such as Holt and Laury (2002) find lower values, we also tested lower $\Phi$ values, but results are qualitatively similar, so they are not presented here.

The CRRA function allows the calculation of the Certainty Equivalent Income (CEI), i.e. the certain income that provides the same utility for a farmer as a given probability distribution of incomes. Since we assume risk aversion, the CE income is lower than the expected income, i.e. the weighted mean of the distribution of incomes. The CEI is computed from the expected utility as explained in equation 6:

$$
C E I^{s t, s c, f}=\left(W^{(1-\phi)}+(1-\phi) E U^{s t, s c, f}\right)^{\frac{1}{1-\phi}}-W
$$

\section{Results and discussion}




\subsection{Control simulation}

The control simulation (Figure 4) is defined by a strong predominance of HK over Somno ( 18\%) and Souna (0\%): Bezançon et al. (2008) provide similar results over the same area and with field observations. Chemical fertilizers are not used at all; they may be useless in some years and are quite expensive, so would be risky to buy. This seems to fit well with what is observed in situ, as shown in Figure 4. Charts with dashes represent results from field observations for years 2004-2007 over the ten locations. According to this observed dataset, HK is also preferred (87\%) to the late Somno variety (13\%). Moreover, fertilizer use is close to simulation even if somewhat more important than in the control (5\% vs $0 \%)$.

Figure 5 shows that CE Income depends on the type of year and is $32 \%$ higher in humid years than in dry years. This is mainly due to the enhanced productivity of Somno and to the positive effect of fertilizers in humid years. Indeed, according to Affholder (1995), with fertilization the crop water demand can exceed the soil water supply. Thus, in dry years, fertilization can have no (or negative) impacts on yields. This might explain differences between humid and dry years. Moreover, Sivakumar (1992) states that with increasing annual rainfall the frequencies of long dry spells decreased. As millet yields are known to be strongly influenced by long dry spells during critical stages (Winkel et al., 1997), this could explain why incomes are weaker in dry years. These arguments also show that predicting the cumulated rainfall over the rainy season could be of interest to farmers. Thus we see in the next section how they react to such a prediction.

\subsection{Adaptation strategies depending on type of forecast}

The chosen cropping strategies presented in Figures $6 \mathrm{a}$ and $6 \mathrm{~b}$ lead to 4 main comments. 
First, cultivar Souna is never used. This is mainly due to the degradation criteria which have a strong impact on simulated yields. Indeed, as this cultivar has a short cycle duration, the date of maturation frequently occurs too early in the season. This is not much better with OFSD: in this case, the sowing date is too late and other cultural strategies are better (HK, Somno...). Vaksmann and Traore (1994) came to a similar conclusion regarding the Souna variety for the Bankass zone of Mali. This does not mean that this cultivar is useless but rather that in this region, and with this kind of forecast, it is not the most powerful. To improve the use of Souna, forecasts based on season duration would be useful. Indeed, if farmers knew that the forthcoming season was going to be short, they could sow Souna as they would not run the risk of yields degraded by pests, moisture problems.

Second, perfect forecasts (Pft) are used to select a main cultural strategy for each type of year: (HK; FSD; NFert) in dry years, (HK; FSD) in normal years, and (Somno, FSD) in humid years. Somno is not used in dry years because the rainy season is, on average, 10 days shorter than in humid years. Thus, during dry years and with FSD, Somno's harvest date is frequently too late and yields are weak because of dry spells during sensitive stages. The impact of fertilizer use in humid years has already been explained. Note that fertilizer use-rate is the same in normal and humid years (30\%) due to fertilizer prices that are $44 \%$ higher.

Third, the selected strategies of the imperfect forecast (Impft) are less risky than with the perfect one $(\mathrm{Pft})$. For example, in the years forecasted as humid there are only 3 years which are effectively dry: the group is more heterogeneous than with the perfect forecast. This explains why the farmers with Impft use much less fertilizer (a risky option) than with Pft, and much more with HK+FSD.

Fourth, when (Pft++) is possible, sowing date based on offset (OFSD) is widely used in all types of years. During dry and normal years, this sowing date is combined mainly with HK (no fertilization), and during humid years with Somno. As with PRE.det, Somno is used 
only in humid years for the same reason as before. ONSD is only used in normal years $(\sim 10 \%)$, and could have been replaced by OFSD without much loss. This sowing date is not used because OFSD performs better: it avoids crop failure. It does not mean that it is useless, rather that in this simulation, OFSD is preferable.

\subsection{Income depending on type of forecast}

As with the control simulation, we translated each cropping strategy into terms of income. All forecasts improve mean income (Figure 7) but not with the same amplitude: $\mathrm{Pft}++$ is the best with $+34 \%$ (all years). This is logical as with this forecast farmers have more adaptation strategies. Pft++ gives particularly good results in humid years $(+53.5 \%$, vs. $+27.5 \%$ in dry years and $+18.5 \%$ in normal years). This tendency is even greater for Pft and Impft: the rise in income is much better in humid years (and even dry years) than in normal years. This describes what Figure 6a shows: in normal years, adaptation strategies are not much different from the control scenario (and are exactly the same for Impft).

The gain for Impft (+6.9\%), which is close to the current state of the art, indicates that such a forecast could have a positive impact for millet growers, especially in humid years. It also provides a noticeable increase in bad years $(+7.1 \%)$, which is very remarkable, as improving lowest incomes is a great challenge. These results are consistent with Patt et al.'s (2005) 2-year Zimbabwe study which used an ex-post approach. These authors found that the use of forecasts was associated with an increase in harvests of $9.4 \%$ across the two years. They also emphasize that this increase is better during the wettest year $(+18.7 \%)$. Predictability, these values are somewhat higher than ours due to a strong correlation between ENSO and Zimbabwean rainfall. 
Such improvements were verified for all low income years (Figure 8) except for the worst one, 1997, where PRE.det gives somewhat lower income. Pft++ generally increased low gains, except in 2004, as Pft. For 3 other years with higher income (2003, 2004, 2007), Pft gives worse results than Ctrl. Each year, this is mainly due to 1 or 2 stations. Details of these years are available in Table 5. Note that all stations concerned are located in the southern part of the study area.

Year 2002 is also interesting to examine, as Pft++ performed much better than for the other years. This very high rise in income compared to the other scenarios is mainly due to stations where Somno was used on all plots (with Pft++). Indeed, the 2002 rainy season is, on average, 7 days longer than the other years of the "humid" group (Figure 9). For some stations sowing only Somno, the rainy season is more than 20 days longer. This provides optimal conditions for this cultivar: gains with Pft++ are therefore better than with "Pft" which uses less Somno.

\section{Conclusion}

Under the assumptions described in this paper, we quantified the economic value for millet growers of different seasonal forecasts in SW Niger for the years 1990-2007. We evaluated 3 different types of forecast of seasonal rainfall: an imperfect tercile forecast of the seasonal rainfall, a perfect tercile forecast and an enhanced forecast system that also predicts the onset and the cessation of the rainy season.

In response to the forecast, farmers are able to choose between 3 millet cultivars, 2 levels of fertilization and (with some types of forecasts only) and 3 sowing dates. The optimal cultural strategy was then chosen, taking into account farmers' risk aversion with a CRRA utility function. 
Results show that even with an imperfect forecast based on a simple relationship between cumulated rainfall and climatic predictors, there is a benefit from using forecasts characterized by an increase of the CE income $(+6.9 \%)$. When the forecast is more accurate, the $\mathrm{CE}$ income increases more $(+11 \%)$ and the best $\mathrm{CE}$ income value is logically found when more adaptation strategies are available $(+31 \%)$. These adaptation strategies presuppose perfect rainy season onset and offset predictions. We also showed that the benefit from the forecast depends on the type of year: the drier the season, the lower the CE income. Indeed, the effects of fertilization are limited in dry years and the likelihood of dry spells is higher. However, the value of forecasts in 'normal' years, relative to the Control scenario, is the lowest. Indeed, as the group 'normal years' is quite heterogeneous (more heterogeneous than dry and humid years) it is more difficult to find a powerful strategy: thus, the chosen management strategies are close to the situation without forecast. Moreover, it is very interesting to emphasize that, in dry years, the value of an imperfect forecast is quite high relative to the Control $(+.7 .1 \%)$. This shows that seasonal forecasting is able to improve the farmers' situation in bad years.

This benefit results from an adaptation of the agricultural strategy to the coming rainy season. Short (long) cycle cultivars such as HK (Somno) without (with) fertilization appeared to be better adapted to dry (humid) years. Indeed the use of fertilizers in dry years lead to a very low increase in yield, while long cycle cultivars performed better in humid years when the rainy season was longer. Finally we found that, even with forecasts, the improved short cycle cultivar Souna does not seem to be adapted to the Niger region. Its cycle is generally too short in comparison with the length of the rainy season and this inadequacy leads to yield losses.

It is necessary to emphasize that these results apply only to a dry region, i.e. the region around Niamey. In a wetter environment, with more adaptation strategies, the value of seasonal forecasts would probably be higher, since more farmers could choose between more 
crops, including potentially more productive but risky crops such as maize (Sultan et al. 2009). Moreover, the role of livestock (buffer stock...) has to be studied in the future in order to have a more global assessment.

Finally, a seasonal forecast system has a non-negligible impact on farmers' income, even when taking the imprecision of the forecast into account. The three scenarios studied (Pft, Impft, Pft++) show, however, that the added value could be much more important if forecast accuracy was improved and/or if other information such as the onset or offset of the rainy season were available.

Moreover, our results are for strongly risk averse farmers: they tend to avoid strategies with high year-to-year variability even if the overall mean income is better. Coupling forecasts with safety nets such as crop insurances could, therefore change significantly the value of forecasts, as explained by Meza et al. (2008). Such insurances have already provided promising results in various regions of the world, e.g., in India (Giné et al., 2007), Malawi (Hellmuth et al., 2007) or West Africa, for maize and peanuts (Berg et al., 2009). So, considering a combination of seasonal forecasts and crop insurance seems to be a promising research direction.

Acknowledgements: the authors would like to thank all the contributors to this work, especially Romain Marteau from CRC Dijon for map designing, John H. Sanders for providing prices of fertilizers and Eric Strobl for his advices to improve the final version.

\section{Bibliography}

Abdoulaye T, Sanders JH. 2005. Stages and determinants of fertilizer use in semiarid African 
agriculture: the Niger experience. Agricultural Economics 32: 167-179

Affholder F. 1995. Effect of organic matter input on the water balance and yield of millet under tropical dryland condition. Field Crops Research 41: 109-121

Alhassane A. 2009. Effet du climat et des pratiques culturales sur la croissance et le développement du mil (Pennisetum Glaucum [L.] R.BR.) au Sahel : Contribution à l'amélioration du modèle SARRA$H$ de prévision des rendements. $\mathrm{PhD}$ thesis of University of Cocody: Abidjan, Côte d'Ivoire. Crops Physiology: 235 p.

Amadou M, Gandah M, Bielders CL, Van Duivenbooden N. 1999. Optimizing soil water use in Niger: research, development, and perspectives. In Efficient Soil Water Use - The Key to Sustainable Crop Production in Dry-Area Agriculture in West Asia, and North and Sub-Saharan Africa. Proceedings of the Workshops Organized by the Optimizing Soil Water Use (OSWU) Consortium, Niamey, Niger, 2630 April 1998 and Amman, Jordan, 9-13 May 1998 (Eds N. Van Duivenbooden, M. Pala, C. Studer \& C.L. Bielders), pp.143-164. Aleppo, Syria: ICARDA and ICRISAT.

Balme M, Galle S, Lebel T. 2005. Démarrage de la saison des pluies au Sahel : variabilité aux échelles hydrologique et agronomique, analysée à partir des données EPSAT-Niger. Sécheresse 16: 15-22

Baron C, Sultan B, Balme M, Sarr B, Traore S, Lebel T, Janicot S, Dingkuhn M. 2005. From GCM grid cell to agricultural plot: scale issues affecting modelling of climate impact. Phil. Trans. R. Soc. B 360: $2095-2108$

Berg A, Quirion P, Sultan B. 2009. Weather-index drought insurance in Burkina-Faso: assessment of its potential interest to farmers. Weather, Climate and Society 1: 71-84 
Bezançon G, Pham J-L, Deu M, Vigouroux Y, Sagnard F, Mariac C, Kapran I, Mamadou A, Gérard B, Ndjeunga J, Chantereau J. 2009. Changes in the diversity and geographic distribution of cultivated millet ( Pennisetum glaucum (L.) R. Br.) and sorghum ( Sorghum bicolor (L.) Moench) varieties in Niger between 1976 and 2003. Genetic Resources and Crop Evolution 56: 223-236

Brüntrup M. 2000. The level of risk aversion among African farmers - results of a gambling approach. Deutscher Tropentag 2000 in Hohenheim:1-10

Cappelaere B, Descroix L, Lebel T, Boulain N, Ramier D, Laurent JP, Le Breton E, Mamadou I, Boubkraoui S, Bouzou Moussa I, . FG, Issoufou HBA, Nazoumou Y, Quantin G, Chaffard V, Ottlé C. 2009. The AMMA-CATCH experiment in the cultivated Sahelian area of south-west Niger -Investigating water cycle response to a fluctuating climate and changing environment. J. Hydrol. 375: $34-51$

Chiappori P-A, Paiella M. 2008. Relative Risk Aversion Is Constant: Evidence from Panel Data Department of economic studies, Discussion paper 5

Cooper PJM, Dimes J, Rao KPC, Shapiro B, Shiferaw B, Twomlow S. 2008. Coping better with current climatic variability in the rain-fed farming systems of sub-Saharan Africa: An essential first step in adapting to future climate change? Agriculture, Ecosystems \& Environment 126: 24-35

Coulibaly P, Evora ND. 2007. Comparison of neural network methods for infilling missing daily weather records. Journal of Hydrology 341: 27-41

de Rouw A. 2004. Improving yields and reducing risks in pearl millet farming in the African Sahel. Agricultural Systems 81: 73-93 
Dingkuhn M, Baron C, Bonnal V, Maraux F, Sarr B, Sultan B, Clopes A, Forest F. 2003. Decision support tools for rainfed crops in the Sahel at the plot and regional. In: Struif Bontkes TE, Wopereis MCS (eds), Decision support tools for smallholder agriculture in sub-Saharan Africa: a practical guide. IFDC: Muscle Shoals, USA.

Dingkuhn M, Singh BB, Clerget B, Chantereau J, Sultan B. 2006. Past, present and future criteria to breed crops for water-limited environments in West Africa. Agricultural Water Management 80: 241261

Druyan LM, Feng J, Cook KH, Xue Y, Fulakeza M, Hagos SM, Konare A, Moufouma-Okia W, Rowell DP, Vizy EK, Ibrah SS. 2009. The WAMME regional model intercomparison study. Climate Dynamics (published online)

Egg J, Wade I. 2006. Bilan et perspectives des cultures vivrières dans les pays du Sahel Santé 16: 271278

FAO. 2002. Niger. Résultats des démonstrations d'engrais au poquet sur mil. Années 1999, 2000 et 2001: 7 p.

FAO. 2008. Recensement général de l'agriculture et du cheptel (RGAC), Niger. Conclusions et recommandations du projet. Programme de coopération FAO/gouvernement

Folland, C.K., Owen, J.A., Ward, M.N., and A.W. Colman, 1991. Prediction of seasonal rainfall in the Sahel region of Africa using empirical and dynamical methods. J. Forecasting. 10: 21-56.

Garcia BIL, Sentelhas PC, Tapia L, Sparovek G. 2006. Filling in missing rainfall data in the Andes region of Venezuela, based on a cluster analysis approach. Rev. Bras. Agrometeorologia 14: 225-233 
Giannini, A., Saravanan, R., and Chang, P. 2003. Oceanic forcing of Sahel rainfall on interannual to interdecadal time scales. Science 302: 1027-1030

Giné X, Townsend R, Vickery J. 2007. Statistical Analysis of Rainfall Insurance Payouts in Southern India. American Journal of Agricultural Economics 89: 1248-1254

Hamatan M, Mahe G, Servat É, Paturel J-E, Amani A. 2004. Synthèse et évaluation des prévisions saisonnières en Afrique de l'Ouest. Sécheresse 15: 279-286

Hansen JW. 2002. Realizing the potential benefits of climate prediction to agriculture: issues, approaches, challenges. Agricultural Systems 74: 309-330

Hansen JW, Mishra A, Rao KPC, Indeje M, Ngugi RK. 2009. Potential value of GCM-based seasonal rainfall forecasts for maize management in semi-arid Kenya. Agricultural Systems 101: 80-90

Hassan R, Nhemachena C. 2008. Determinants of african farmers' strategies for adapting to climate change: Multinomial choice analysis. AfJARE 2: 83-104

Hellmuth M, Moorhead A, Thomson M, Williams J. 2007. Gestion du risque climatique en Afrique : ce que la pratique nous enseigne. Institut National de Recherche pour le climat et la société (IRI): New York, USA.

Holt CA, Laury SK. 2002. Risk Aversion and Incentive Effects American Economic Review 92: 16441655

Ingram KT, Roncoli MC, Kirshen PH. 2002. Opportunities and constraints for farmers of West Africa to use seasonal precipitation forecasts with Burkina Faso as a case study. Agricultural Systems 74: 331-349 
Konte O. 2007. Méthodologie d'analyse de la performance et d'interprétation des prévisions saisonnières des précipitations (PRESAO): application à la culture du mil au Sénégal. Master thesis of Centre Régional Aghrymet: Niamey, Niger: 49 p.

Kouressy M, Dingkuhn M, Vaksmann M, Heinemann AB. 2008. Adaptation to diverse semi-arid environments of sorghum genotypes having different plant type and sensitivity to photoperiod. Agricultural and Forest Meteorology 148: 357-371

Laux P, Kunstmann H, Bardossy A. 2008. Predicting the regional onset of the rainy season in West Africa. International Journal of Climatology 28: 329-342

Letson D, Laciana CE, Bert FE, Weber EU, Katz RW, Gonzalez XI, Podestá GP. 2009. Value of perfect ENSO phase predictions for agriculture: evaluating the impact of land tenure and decision objectives. Climatic Change 97: 145-170

Luseno WK, McPeak JG, Barrett CB, Little PD, Gebru G. 2003. Assessing the Value of Climate Forecast Information for Pastoralists: Evidence from Southern Ethiopia and Northern Kenya. World Development 31: 1477-1494

Marteau R, Sultan B, Baron C, Traoré S, Alhassane A, Moron V. forthcoming. The onset of the rainy season and the farmers' sowing strategy for pearl millet in Southwest Niger. Submitted to International Journal of Climatology

Meza FJ, Hansen JW, Osgood D. 2008. Economic value of seasonal climate forecasts for agriculture: Review of ex-ante assessments and recommendations for future research. Journal of Applied Meteorology and Climatology 47: 1269-1286 
O'Brien K, Sygna L, Næss LO, Kingamkono R, Hochobeb B. 2000. Is Information Enough? User Responses to Seasonal Climate Forecasts in Southern Africa. Report to the World Bank, AFTE1ENVGC. Adaptation to Climate Change and Variability in Sub-Saharan Africa, Phase II 1-72

Ogurtsov VA, Van Asseldonk MPAM, Huirne RBM. 2008. Assessing and modelling catastrophic risk perceptions and attitudes in agriculture: a review. NJAS - Wageningen Journal of Life Sciences 56: 3958

Patt A, Suarez P, Gwata C. 2005. Effects of seasonal climate forecasts and participatory workshops among subsistence farmers in Zimbabwe. PNAS 102: 12623-12628

Romero R, Guijarro J, Alonso S. 1998. A 30 year (1964-1993) daily rainfall data base for the Spanish Mediterranean regions: first exploratory study. International Journal of Climatology 18: 541-560

Roncoli C, Ingram K, Kirshen P. 2001. The costs and risks of coping with drought: livelihood impacts and farmers' responses in Burkina Faso. Climate Research 19: 119-132

Roncoli C, Ingram K, Kirshen P. 2002. Reading the rains: Local knowledge and rainfall forecasting in Burkina Faso. Society \& Natural Resources 15: 409-427

Roncoli C, Jost C, Kirshen P, Sanon M, Ingram KT, Woodin M, Somé L, Ouattara F, Sanfo BJ, Sia C, Yaka P, Hoogenboom G. 2009. From accessing to assessing forecasts: an end-to-end study of participatory climate forecast dissemination in Burkina Faso (West Africa). Climatic change 92: 433460

Rubas D, Harvey S, Hill J, Mjelde JW. 2006. Economics and climate applications: exploring the frontier. Climate Research 33: 43-54 
Schechter L. 2007. Risk aversion and expected-utility theory: A calibration exercise Journal of Risk and Uncertainty 35: 67-76

Sivakumar MVK. 1988. Predicting rainy season potential from the onset of rains in Southern Sahelian and Sudanian climatic zones of West Africa. Agricultural and Forest Meteorology 42: 295-305

Sivakumar MVK. 1992. Empirical-Analysis of Dry Spells for Agricultural Applications in West Africa. Journal of Climate 5: 532-539

Smith, T.M., Reynolds, R.W., Peterson, T.C., and J. Lawrimore, 2008. Improvements to NOAA's historical merged land-ocean surface temperature analysis (1880-2006). J. Climate 21: 2283-2296

Soler CMT, Maman N, Zhang X, Mason SC, Hoogenboom G. 2008. Determining optimum planting dates for pearl millet for two contrasting environments using a modelling approach. J. Agricultural Science 146: 445-459

Sultan B, Barbier B, Fortilus J, Mbaye S, Leclerc G. 2009. Estimating the potential economic value of the seasonal forecasts in West Africa: a long-term ex-ante assessment in Senegal. Weather, Climate and Society: in press.

Sultan B, Baron C, Dingkuhn M, Sarr B, Janicot S. 2005. Agricultural impacts of large-scale variability of the West African monsoon. Agricultural and Forest Meteorology 128: 93-110

Sultan B, Janicot S. 2003. The West African monsoon dynamics. Part II : The "pre-onset" and the "onset" of the summer monsoon. Journal of Climate 16: 3407-3427

Tarhule A, Lamb PJ. 2003. Climate research and seasonal forecasting for West Africans - Perceptions, dissemination, and use? Bulletin of the American Meteorological Society 84: 1741-1759 
Teegavarapu RSV, Chandramouli V. 2005. Improved weighting methods, deterministic and stochastic data-driven models for estimation of missing precipitation records. Journal of Hydrology 312: 191206

Traore PCS, Kouressy M, Vaksmann M, Tabo R, Maikano I, Traore SB, Cooper R. 2007. Climate prediction and agriculture: What is different about Sudano-Sahelian West Africa? In: Sivakumar MVK, Hansen JW (eds), Climate Prediction and Agriculture: Advances and Challenges. Springer Berlin Heidelberg

Vaksmann M, Traoré SB. 1994. Adéquation entre risque climatique et choix variétal du mil. Cas de la zone de Bankass au Mali. In: John Libbey Eurotext (eds), Bilan hydrique agricole et sécheresse en Afrique tropicale, Paris.

Vaksmann M, Traoré SB, Niangado O. 1996. Le photopériodisme des sorghos africains. Agriculture et Développement 9: 13-18

Wakker PP. 2008. Explaining the characteristics of the power (CRRA) utility family. Health Economics 17: 1329-1344

Ward, M.N., 1998. Diagnosis and short-lead time prediction of summer rainfall in tropical north Africa at interannual and multidecadal timescales. J. Climate 11: 3167-3191.

Ward N, Cook K, Diedhiou A, Fontaine B, Giannini A, Kamga A, Lamb P, Ben Mohamed A, Nassor A, Thorncroft C. 2004. Seasonal-to-decadal predictability and prediction of West African climate. CLIVAR Exchanges 9: 14-20

Winkel T, Renno J-F, Payne WA. 1997. Effect of the timing of water deficit on growth, phenology 
and yield of pearl millet (Pennisetum glaucum (L.) R. Br.) grown in Sahelian conditions. Journal of Experimental Botany 48: 1001-1009

Ziervogel G, Bithell M, Washington R, Downing T. 2005. Agent-based social simulation: a method for assessing the impact of seasonal climate forecast applications among smallholder farmers. Agricultural Systems 83: 1-26 
TABLES

\section{Simulated data}

\begin{tabular}{cccccc}
\hline & Interval (mm) & {$[0 ; 1]$} & ] $1 ; 10]$ & ] $10 ; 20]$ & $>20$ \\
\hline \multirow{2}{*}{ Observed } & {$[0 ; 1]$} & 91.0 & 8.0 & 0.9 & 0.1 \\
data & ] $1 ; 10]$ & 17.4 & 65.2 & 14.0 & 3.4 \\
& $>20$ & 5.3 & 43.5 & 35.3 & 15.9 \\
& $110 ; 20]$ & 1.5 & 16.1 & 31.4 & 51.0
\end{tabular}

Table 1: assessment of the data filling method. 1990/2006 are used for calibration, 2007 for validation. 


\begin{tabular}{|c|c|c|c|}
\hline Study & Country & Adaptation Strategies & Comments \\
\hline & & $\begin{array}{l}\text { Change planting date } \\
\text { Change crop locations } \\
\text { Change crop types }\end{array}$ & \\
\hline $\begin{array}{c}\text { O’Brien et al., } \\
2000\end{array}$ & $\begin{array}{l}\text { Tanzania, } \\
\text { Namibia, } \\
\text { South Africa }\end{array}$ & $\begin{array}{c}\text { Inter-crop } \\
\text { Use fertilizer } \\
\text { Store more food } \\
\text { Reduce amount planted } \\
\text { Stop farm activities }\end{array}$ & $\begin{array}{l}\text { A lot of farmers did not do } \\
\text { anything in the pilot study }\end{array}$ \\
\hline & & $\begin{array}{l}\text { Change crop types } \\
\text { Reduce herd sizes }\end{array}$ & Heterogeneity in West Africa \\
\hline $\begin{array}{l}\text { Tarhule and } \\
\text { Lamb, } 2003\end{array}$ & West Africa & $\begin{array}{l}\text { Change grazing methods } \\
\text { Change planting time } \\
\text { Relocate }\end{array}$ & $\begin{array}{l}\text { Malians are less sceptical. } \\
\text { Results are presented here for } \\
\text { Niger. }\end{array}$ \\
\hline $\begin{array}{c}\text { Ingram et al.* } \\
\text { (2002) }\end{array}$ & Burkina Faso & $\begin{array}{l}\text { Plant shorter duration crops/varieties } \\
\text { Plant drought tolerant crops/varieties } \\
\text { +or- manure and fertilizer } \\
\text { Store/sell grain stocks. } \\
\text { Orient furrows across slope } \\
\text { Acquire capital to purchase inputs } \\
\text { Ration food }\end{array}$ & $\begin{array}{l}\text { Classification depending on } \\
\text { the kind of year ('good' or } \\
\text { 'bad'). Only some strategies } \\
\text { are shown here. }\end{array}$ \\
\hline $\begin{array}{c}\text { Ziervogel et } \\
\text { al., } 2005\end{array}$ & Lesotho & $\begin{array}{l}\text { Adjustment of cropping density } \\
\text { Ratio maize to sorghum planted }\end{array}$ & $\begin{array}{l}\text { Both parameters used in a } \\
\text { model. Other strategies are } \\
\text { described briefly. }\end{array}$ \\
\hline Luseno et al., & Ethiopia and & 'Adjust cultivation choices' & "Less than $10 \%$ of those who \\
\hline
\end{tabular}




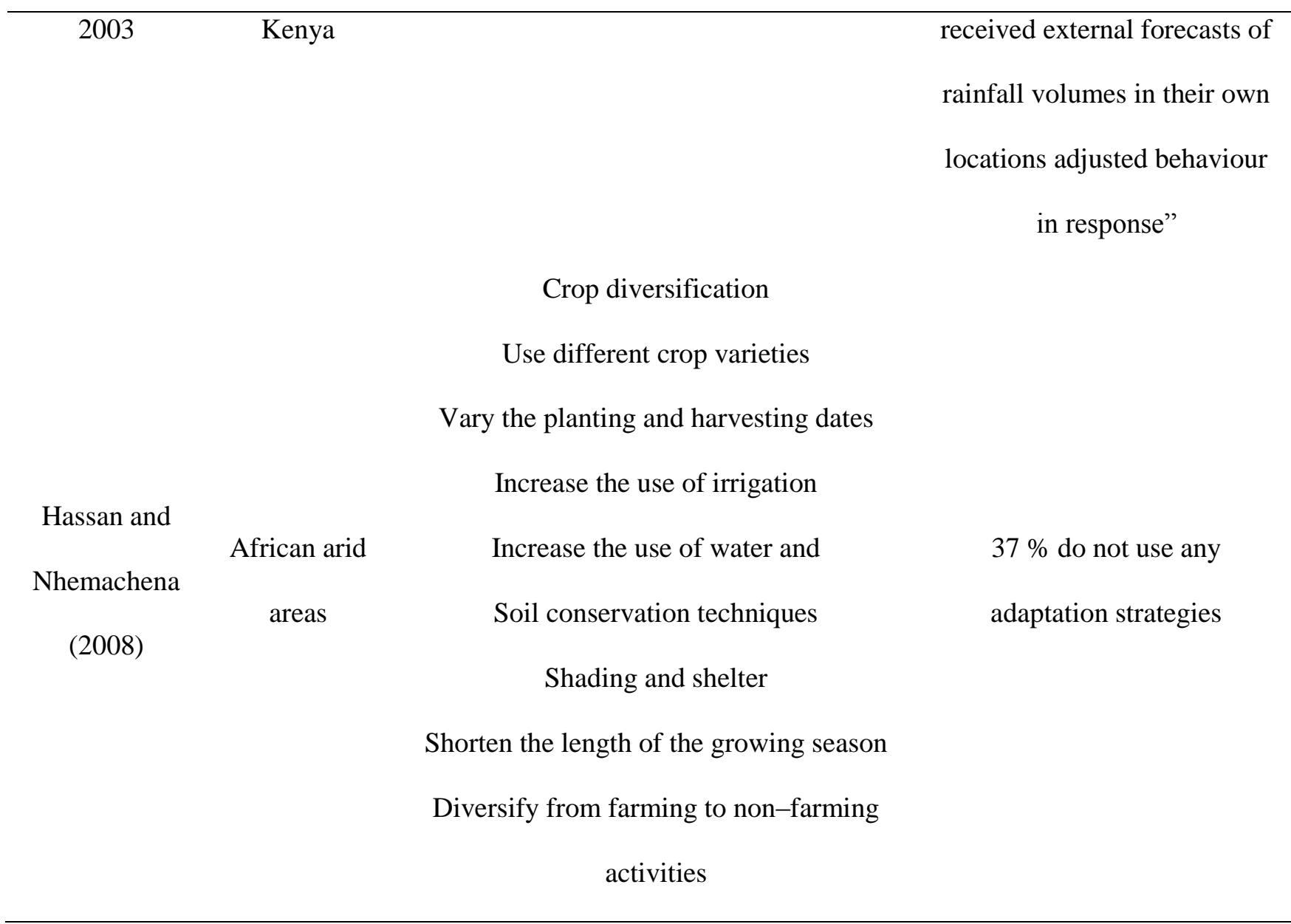

Table 2 : review of possible adaptation strategies to seasonal forecast (cited by farmers).

*Other strategies are described p.343 of this paper depending on the kind of forecast

\begin{tabular}{llccc}
\hline & \multicolumn{4}{c}{ Imperfect Forecast « Impft » } \\
\hline & Category & Dry & Normal & Humid \\
\hline Perfect Forecast «Pft » & Dry & $\mathbf{4}$ & 2 & 0 \\
(observations) & Normal & 1 & $\mathbf{2}$ & 3 \\
& Humid & 1 & 2 & $\mathbf{3}$ \\
\hline
\end{tabular}

Table 3 : differences between both forecast. 


\begin{tabular}{|c|c|c|c|c|c|}
\hline Scenario & Type of forecast & $\begin{array}{l}\text { Sowing } \\
\text { dates } \\
\text { allowed }\end{array}$ & $\begin{array}{c}\text { Cultivars } \\
\text { possible }\end{array}$ & Fertilization & Comments \\
\hline "Ctrl" & None & Only FSD & $\begin{array}{l}\text { HK/Somno } \\
\text { /Souna }\end{array}$ & Yes/No & Same strategy each year \\
\hline "Impft" & $\begin{array}{l}\text { Imperfect deterministic } \\
\text { forecast of seasonal } \\
\text { rainfall }\end{array}$ & Only FSD & $\begin{array}{l}\text { HK/Somno } \\
\text { /Souna }\end{array}$ & Yes/No & $\begin{array}{l}\text { Choose cultivar and } \\
\text { level of fertilization for } \\
\text { each type of rainy } \\
\text { season }\end{array}$ \\
\hline "Pft" & $\begin{array}{l}\text { Perfect deterministic } \\
\text { forecast of seasonal } \\
\text { rainfall }\end{array}$ & Only FSD & $\begin{array}{l}\text { HK/Somno } \\
\text { /Souna }\end{array}$ & Yes/No & $\begin{array}{l}\text { Choose cultivar and } \\
\text { level of fertilization for } \\
\text { each type of rainy } \\
\text { season }\end{array}$ \\
\hline "Pft++" & $\begin{array}{l}\text { Perfect deterministic } \\
\text { forecast of seasonal } \\
\text { rainfall + onset and } \\
\text { cessation of the rainy } \\
\text { season }\end{array}$ & $\begin{array}{c}\text { FSD/ONSD } \\
\text { /OFSD }\end{array}$ & $\begin{array}{l}\text { HK/Somno } \\
\text { /Souna }\end{array}$ & Yes/No & $\begin{array}{l}\text { - Choose cultivar and } \\
\text { level of fertilization, for } \\
\text { each type of rainy } \\
\text { season. } \\
\text {-Adapt sowing date } \\
\text { based on onset/offset. }\end{array}$ \\
\hline
\end{tabular}

Table 4 : Main assumptions in each scenario 


\begin{tabular}{ccc}
\hline Year (type) & Stations & Explanation \\
\hline 1997 (dry) & Tanaberi & Fertilizers used with information Pft are useless \\
2003 (normal) & Karé & For Karé: same reasons as in 2003 \\
2004 (dry) & Karé and Tanaberi & For Tanaberially same reasons as in $1997+$ Karé in 2003 \\
& Tanaberi and & \\
2007 (normal) & Torodi & Same reasons as for Karé in 2003 \\
& & \\
\hline
\end{tabular}

Table 5: why years 1997, 2003, 2004 and 2007 have lower gains with Pft than with Ctrl

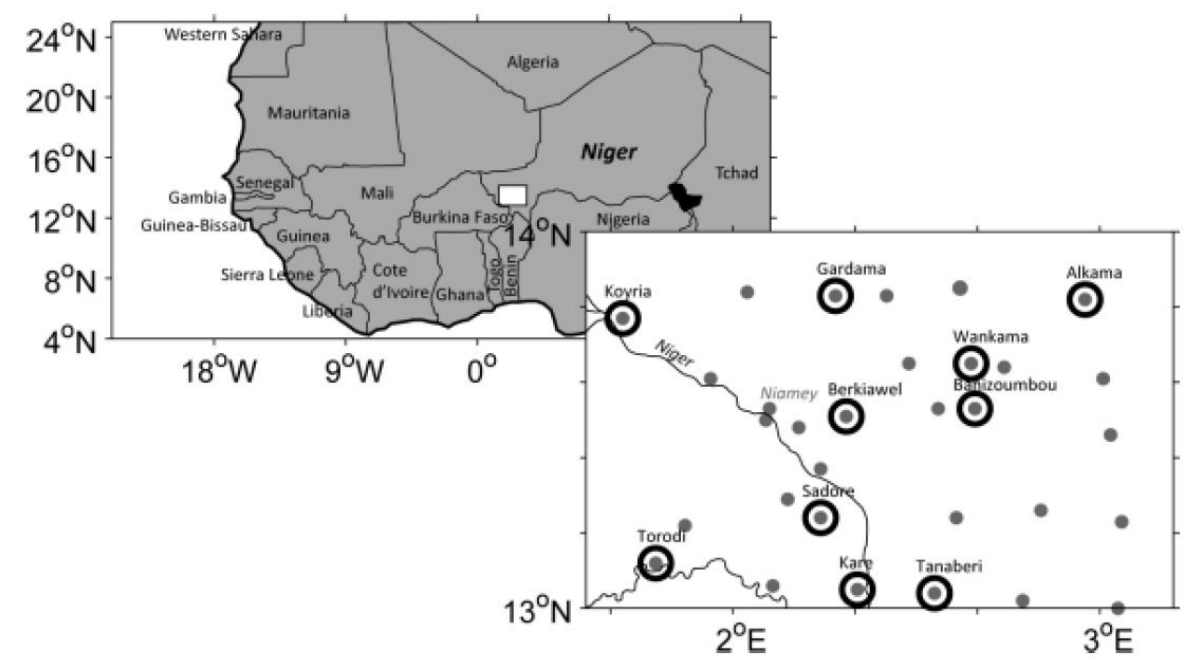

Figure 1. Study area. Simple points represent stations with daily rainfall data. Circles shows villages with yields data (simulation possible). 
(a)

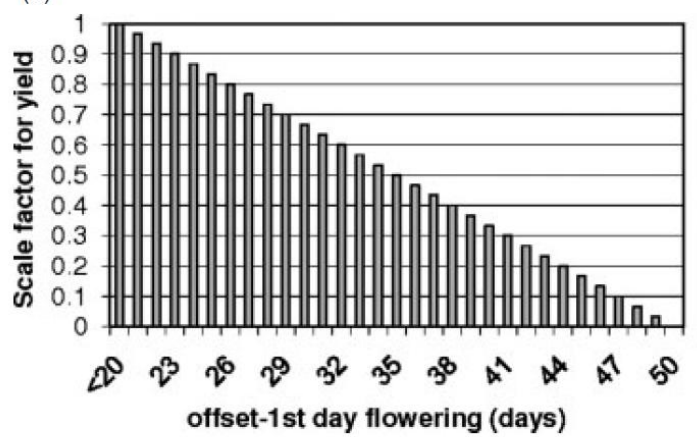

(b)

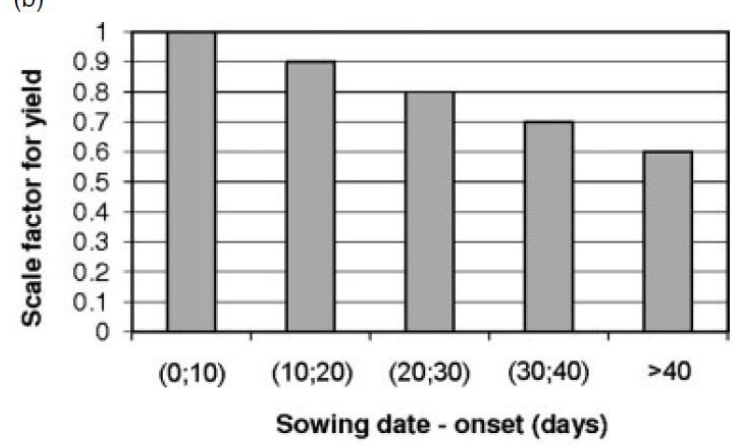

Figure 2. Scale factor values $k$ to compute effective yields (with yields from crop model as inputs) for onset (a), and offset (b) adaptation. Yield $=k \times$ yield simulated.

\section{Variety}

\section{Sowing date}

\section{Fertilization}

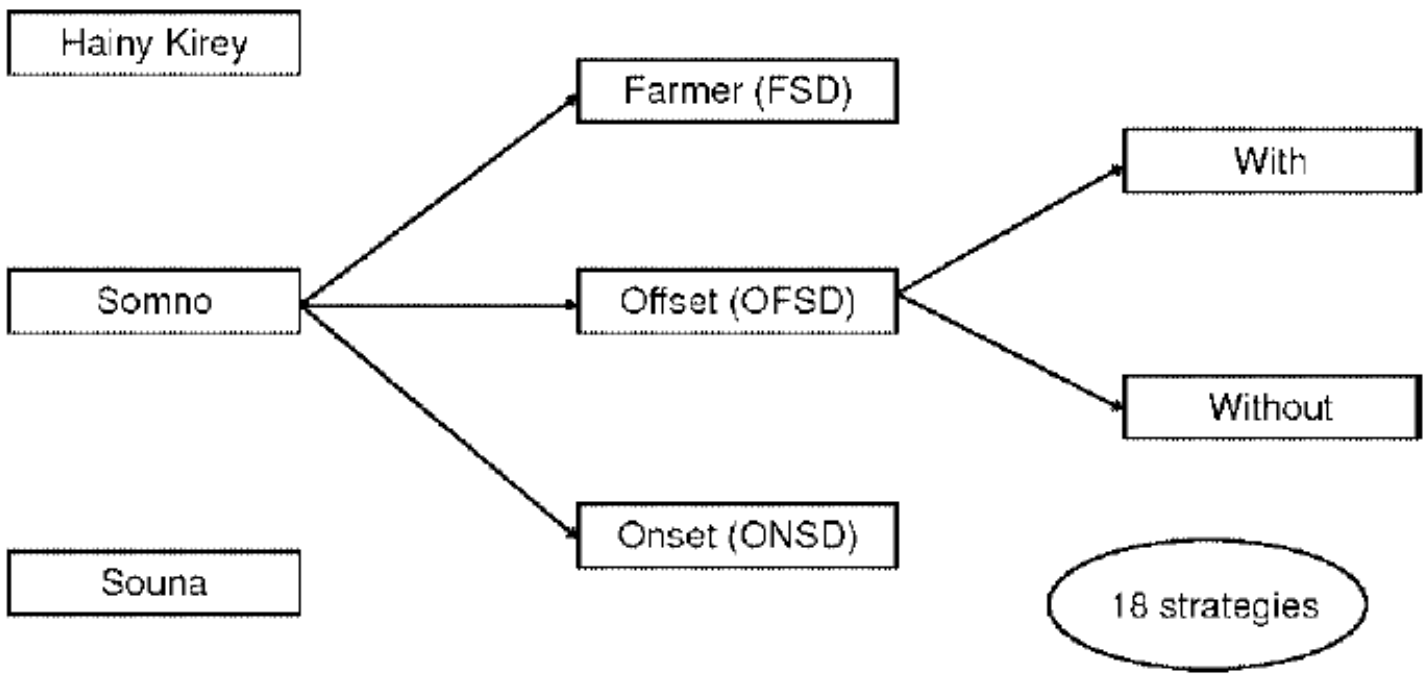

Figure 3. Summary of cultural strategies. 


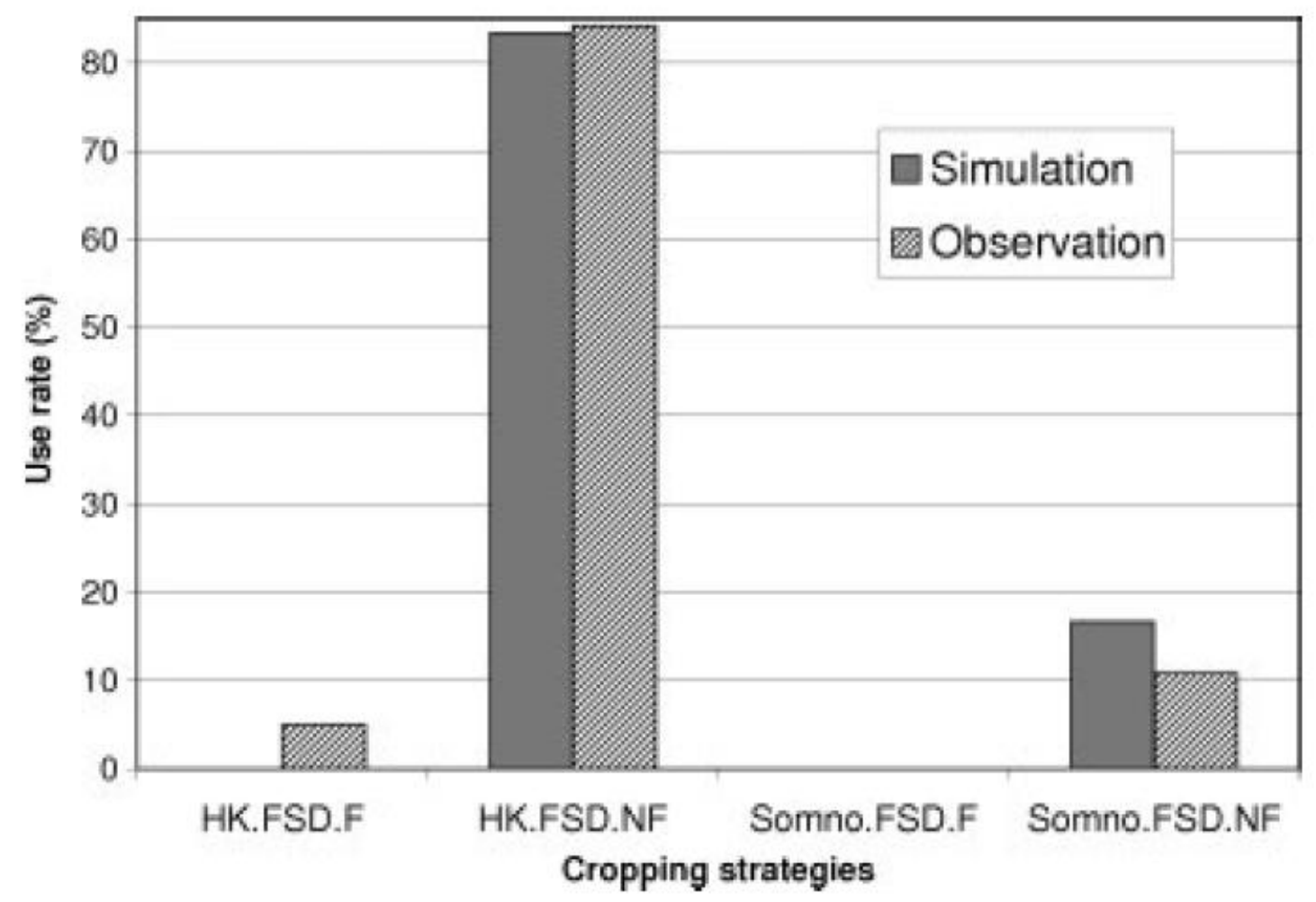

Figure 4. Cropping strategies used according to the control simulation and comparison with observed practices. 


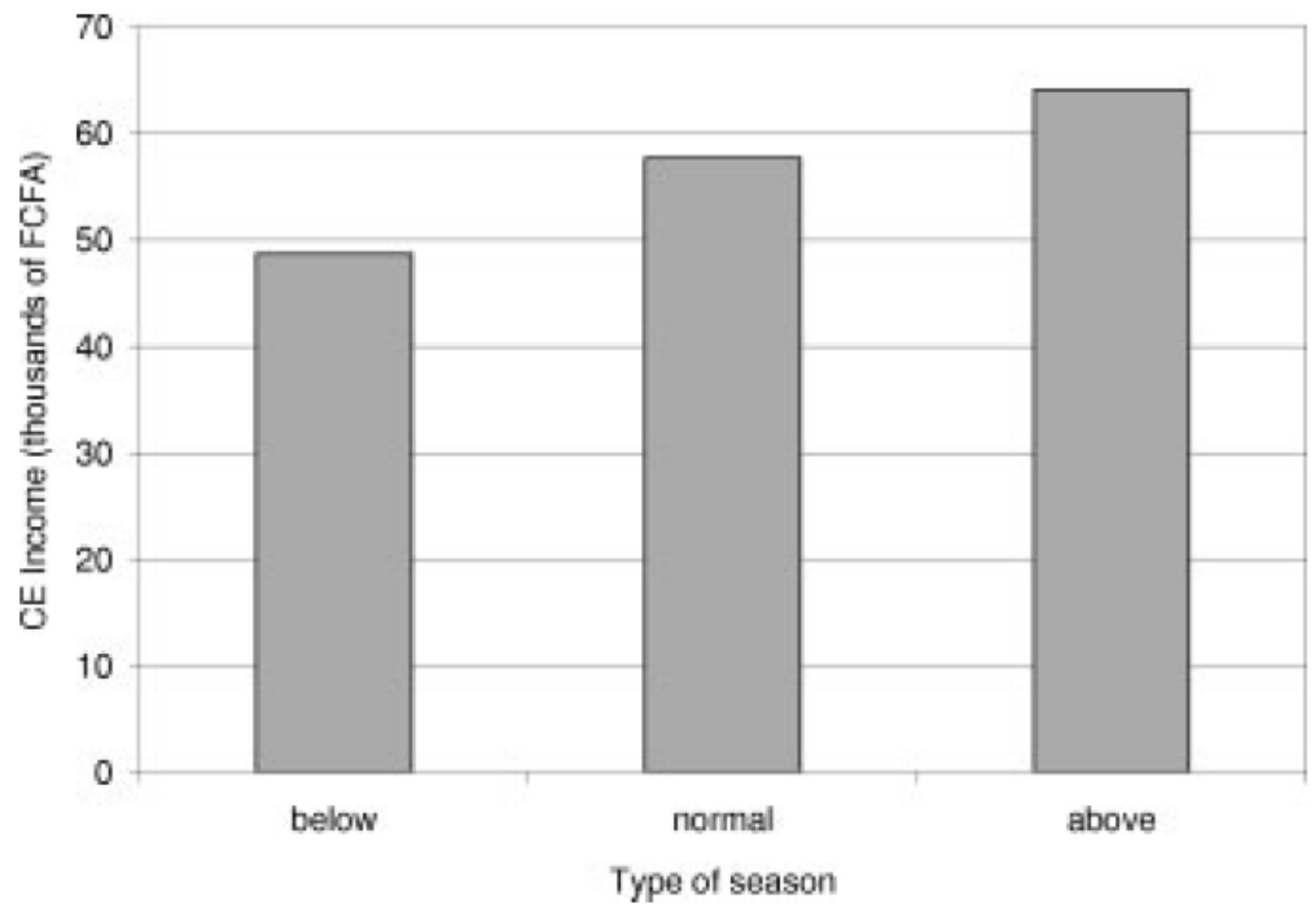

Figure 5. CE Income (mean over the 10 locations) in the control simulation (Ctrl), cluster by cluster. 
(a)

\section{Control}
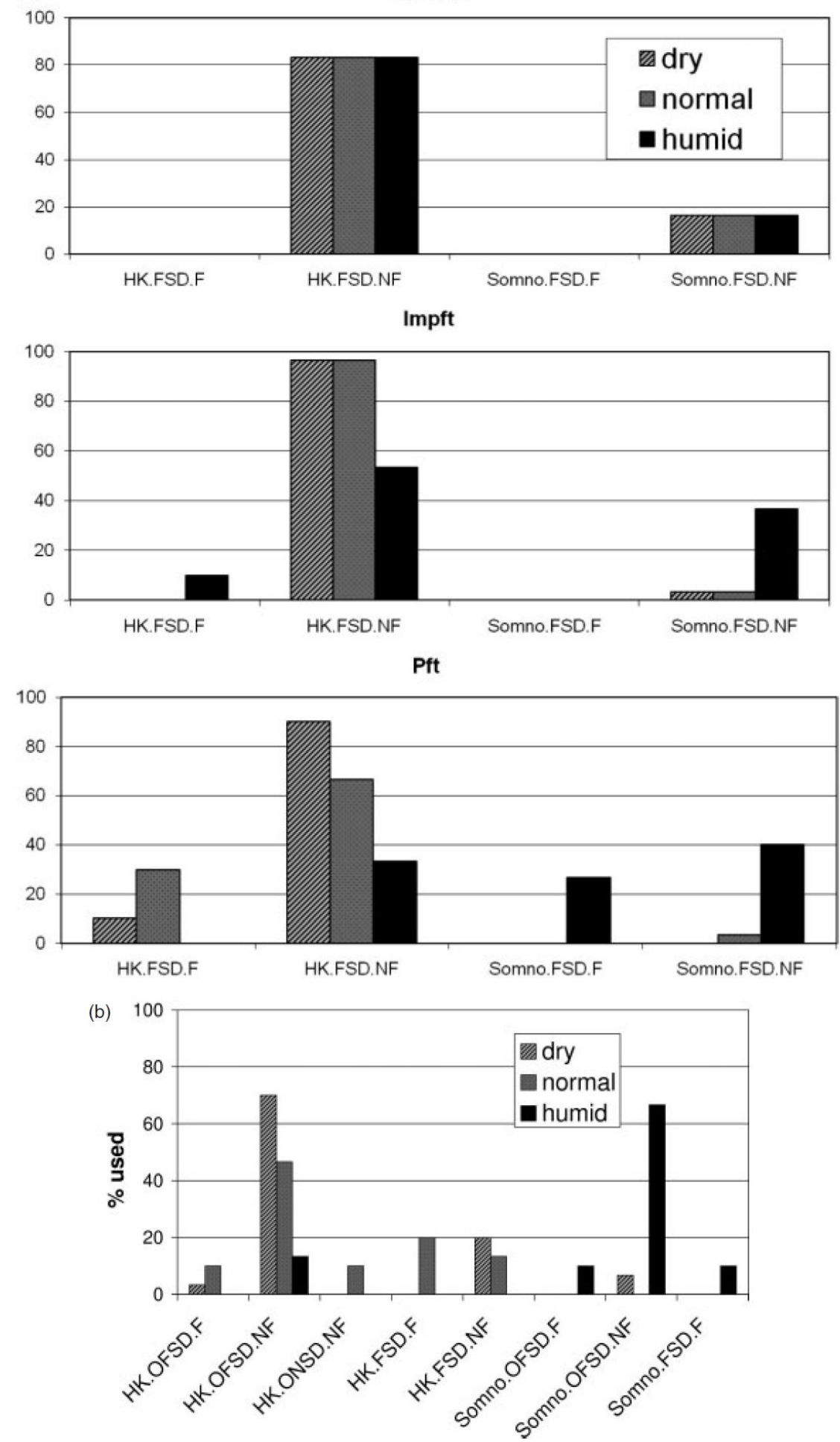

Figure 6. (a) Rate ( $y$-axis, \%) of cropping strategies ( $x$-axis) used by farmers, depending on the kind of forecast; (b) Rate ( $y$-axis, \%) of cropping strategies $(x$-axis) used by farmers, for 'Pft++'. 


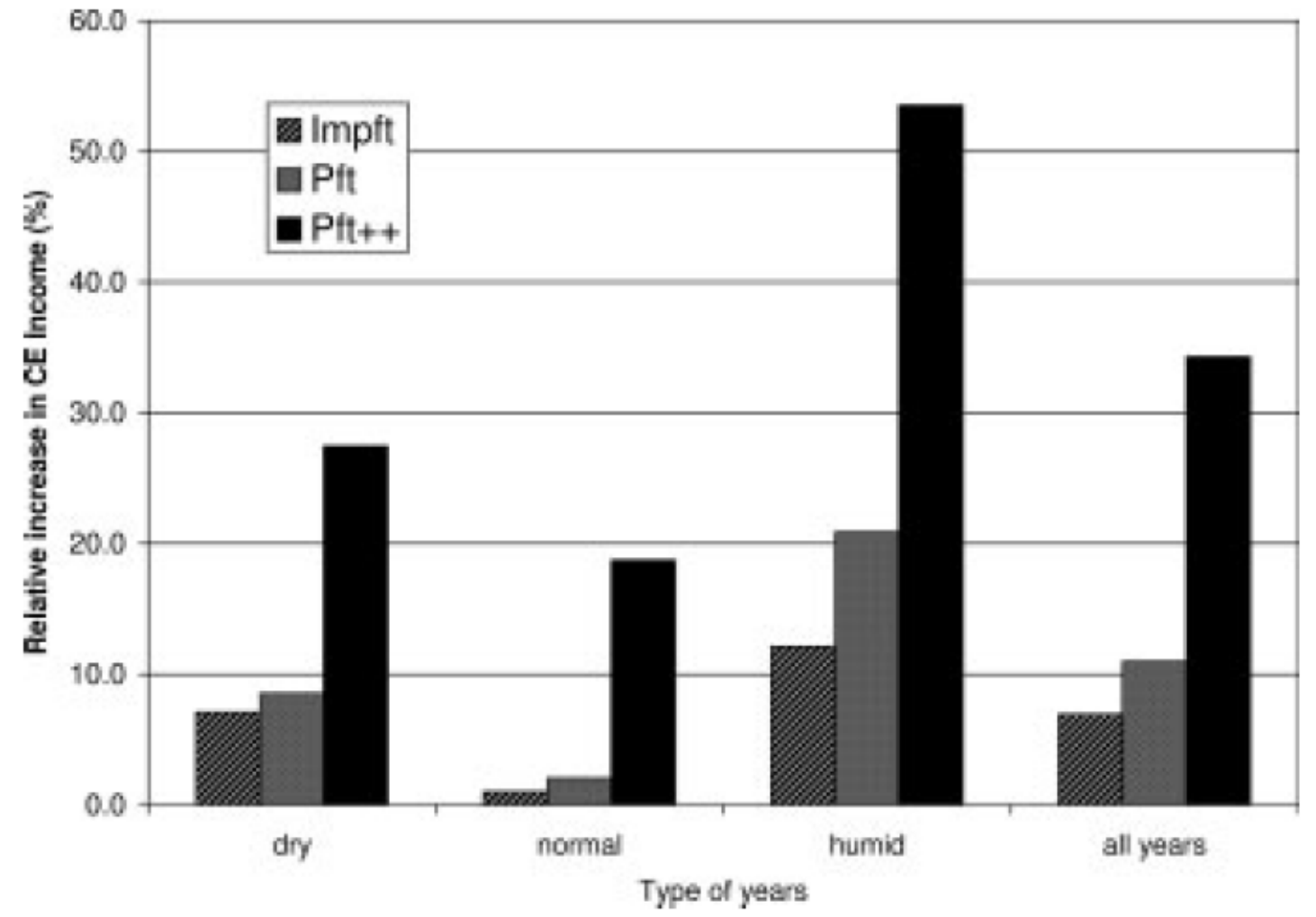

Figure 7. Increase in CE income, relatively to the control scenario, averaged over the 10 locations. 


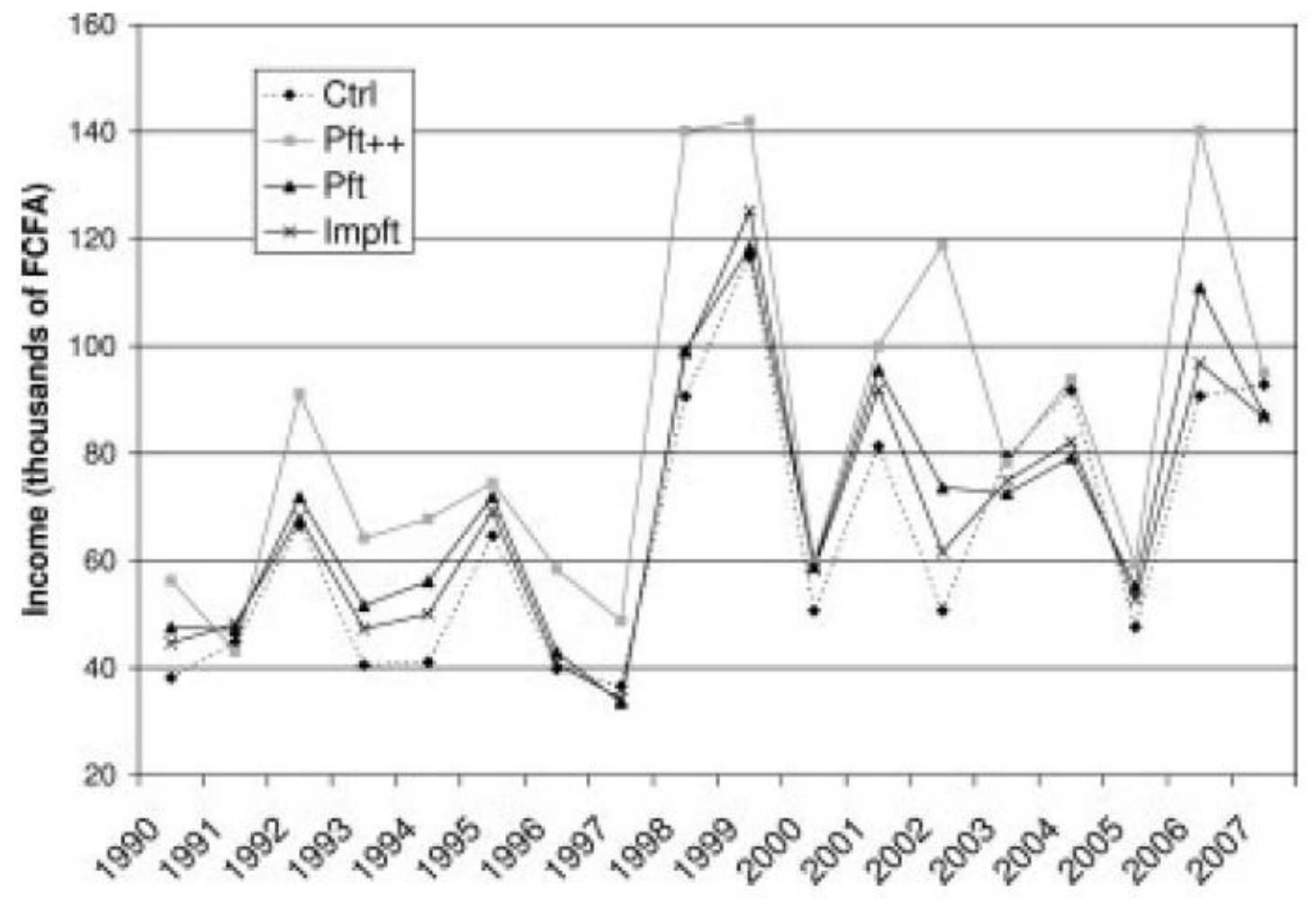

Figure 8. Evolution of the income, year by year, averaged over the 10 locations.

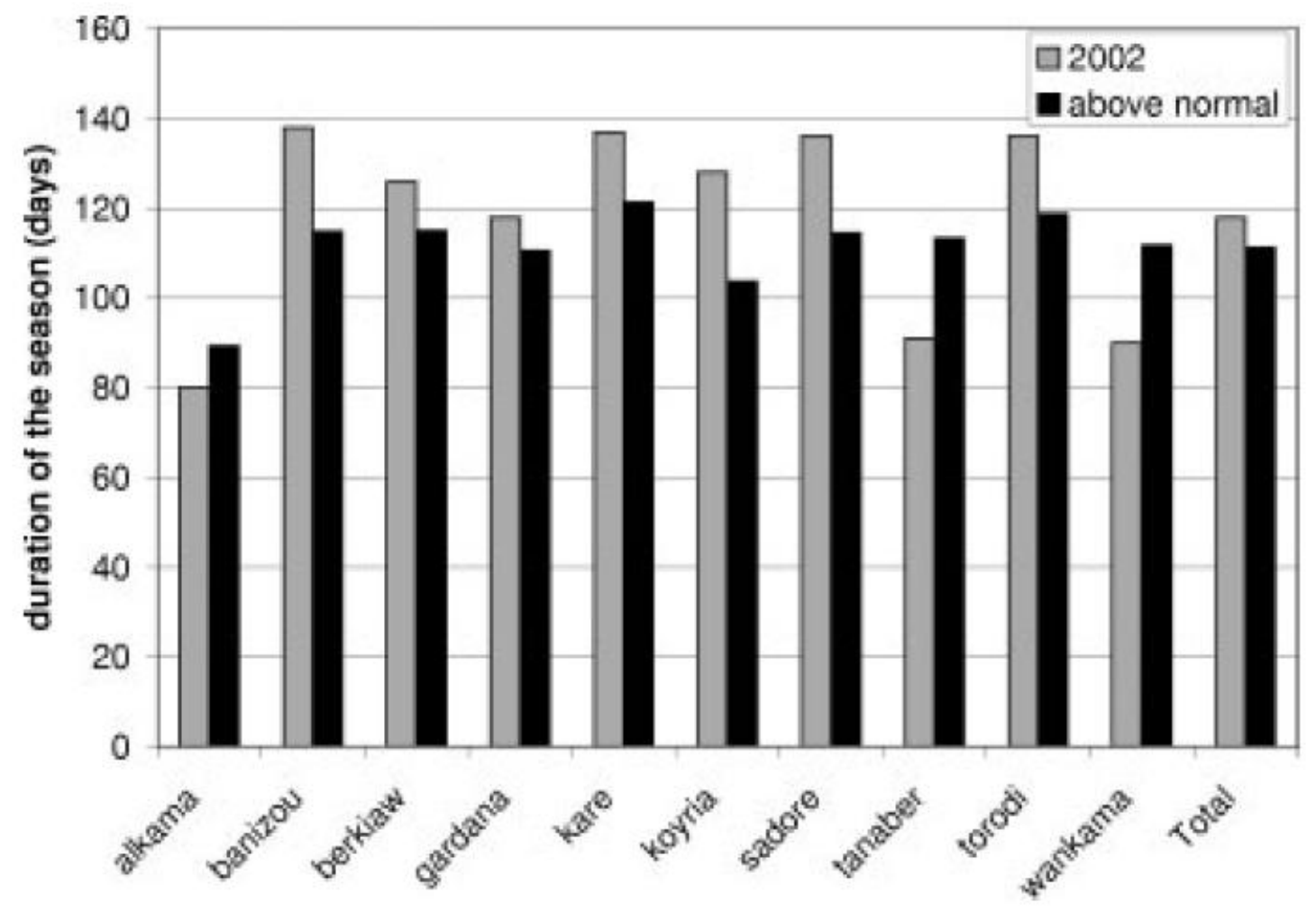

Figure 9. Duration of the rainy season for 2002 and humid years. 